\title{
The Increments and Transformations Institute at the University of South Florida: A Case Study
}

\author{
Grandon Gill, William Patterson and Diane Williams \\ University of South Florida \\ Tampa, Florida USA
}

gqill@coba.usf.edu patterson@cte.usf.edu dwilliams@cte.usf.edu

\begin{abstract}
The paper presents a research case study that describes the three year history of the Increments and Transformations Institute (ITI) at the University of South Florida. The ITI's goal is to encourage faculty members from all disciplines to enhance the effectiveness of their teaching through the appropriate use of technologies and pedagogical strategies. Institute participation consists of a year-long cohort-based program of faculty development divided into three distinct phases. In Phase I, participating faculty members attend an intensive week-long workshop on teaching with technology. Phase II takes place during the fall semester that follows, during which time each participant must implement a single technology-based/pedagogically-informed change to one or more courses (a.k.a., an "increment"). During Phase III, in the spring, each participant must share his or her experiences with additional departmental and college colleagues in a formal setting. There is also an optional Phase IV, during which participants may return to the institute and act as facilitators for subsequent cohorts.

Since it was established, the ITI's organization and approach has undergone two significant changes, moving from extensive reliance on outside facilitators to almost exclusive use of former participants and moving from traditional workshop activities to a structure based around teaching cases. This case study considers how these changes impacted outcomes and have led to an approach to faculty development that is both highly effective and increasingly self-sustaining.
\end{abstract}

Keywords: Educational technology, case method, faculty development, peer instruction, teaching cases, educational leadership

This case study is copyrighted by the Informing Science Institute. Permission to make digital or paper copy of part or all of these works for personal or classroom use is granted without fee provided that the copies are not made or distributed for profit or commercial advantage AND that copies 1) bear this notice in full and 2) give the full citation on the first page. It is permissible to abstract these works so long as credit is given. To copy in all other cases or to republish or to post on a server or to redistribute to lists requires specific permission and payment of a fee. Contact Publisher@InformingScience.org to request redistribution permission.

\section{Introduction}

How can emerging technologies contribute to faculty members' teaching goals? That is the central question that motivated the formation of the Increments and Transformations Institute (ITI) at the University of South Florida - the subject of the present case study. As the case will illustrate, the nature of the ITI changed significantly during its first three years. The changes were driven by adapting techniques commonly used in business 
management education-most notably, the case method — to the task of helping higher education faculty better understand the benefits (and pitfalls) of harnessing new technologies in their teaching practice. Prior to presenting the details of the case, it is useful to explore the underlying assumptions that led to the ITI's present design.

There are many parallels that can be drawn between effective management and effective teaching. One that is particularly strong is how theory relates to practice. Some domains-particularly those dealing with physical and, to a lesser extent, biological systems - are blessed with a straightforward relationship between theory and practice. Students who master a set of theories and principals can use these to develop mental models that can be used to predict complex system behaviors (de Kleer and Brown, 1981). What distinguishes expertise from novice problem solvers is the ability to look beneath the surface attributes of the system and determine the appropriate principals to apply (Chi and Glaser, 1985). In these disciplines, there can be no question regarding the need to master theory in order to practice effectively - those who can't apply the theory are unable to predict the behavior of the system.

Unfortunately, in both management practice and teaching, no such verifiable relationship between theory and practice exists. To the contrary, there is a debate that has raged for decades in both disciplines as to whether or not mastery of formal theory is a prerequisite for-or even beneficial to-effective practice. In management, both academics (e.g., Pascoe, 1992) and practitioners (e.g., Peters and Waterman, 1983) have raised questions relating to the benefits of emphasizing theory and analysis in management education. Indeed, some have gone so far as to assert that such emphasis may actually lead to the decline of U.S. businesses (Hayes and Abernathy, 1980). Observed examples that appear to contradict the need for theory to inform practice also abound. If formal theory is so critical, how can it be that the two most successful entrepreneurs of our time (i.e., Sam Walton and Bill Gates) managed to make their fortunes without any formal — much less graduate—business training? We might also observe that the graduate business program that has historically been most effective in placing its graduates in leadership positions-Harvard Business School (which during the 1980s boasted that $19 \%$ of the Fortune 500 leaders were graduates of its programs) - has, for most of its existence, placed little or no emphasis on attempting to convey formal theory, instead choosing to rely on case discussions as its sole pedagogy. Analogous to management, the debate regarding the relative importance of theory and practice in teacher education has existed as long as the field itself (Jones, 1998). In this context, the implications go far beyond that of a simple thought exercise. An education program's position on the debate has major ramifications with respect to the role played by internships vs. classroom training in its curriculum (e.g., Brunetti, 1998). As was the case for management, it is easy to come up with examples supporting the side of practice, particularly in the case of higher education. Outside of the education field itself, relatively few faculty members have formal training in educational theory. Does this mean we can therefore conclude that good teaching cannot exist outside of colleges of education? Such a conclusion would fly in the face of all experience.

A second parallel between business and education practice is that while mastery of formal theory may not be a prerequisite for effective practice, there are a number of fundamental skills that are critical. In assessing what they are looking for in university graduates, managers invariably mention attributes such as "good communications skills" and "good problem solving skills" (Gill, 2005). In teaching, the value of the ability to communicate effectively is self-evident. As for problem solving, it is at the heart of the educational concept referred to as "critical thinking"—a capability viewed as being so important that its measured presence in higher education is being mandated in many states (e.g., Florida's Academic Learning Compacts).

A third skill that has become increasingly critical over the past two decades in both management and teaching is the ability to use technology effectively. A few decades ago, IT's most profound impacts on management and teaching were limited to a few disciplines (e.g., mathematics and the sciences) and to a few business functions (e.g., data processing, accounting, engineering, operations). At that time, individuals could manage and faculty could teach with few-if any_technological tools. Today, that 
stance is becoming increasingly impractical. In the world of business, it is nearly impossible to access the information needed to compete without employing technology. In higher education, institutional demands for productivity - coupled with the demands of students who have grown accustomed to certain types of support (e.g., having lecture notes available electronically, being able to check their progress online)— make it difficult for most faculty members to avoid implementing at least some technology tools in their classes.

These parallels between management and teaching have proven to be powerful forces in the path that has been followed by the ITI. In the case study that follows, we examine how case method techniques developed for teaching management have been adapted to the purpose of informing faculty members on how to incorporate technology into their classes. We also present evidence of the effectiveness of these techniques.

\section{$\mathrm{C}^{21} \mathrm{TE}$}

The Center for $21^{\text {st }}$ Century Teaching Excellence $\left(\mathrm{C}^{21} \mathrm{TE}\right)$ is located at the University of South Florida, a large, metropolitan, Research I member of Florida's state university system, whose main campus is located in Tampa Florida. Originally, referred to as the Center for Teaching Enhancement, the $\mathrm{C}^{21} \mathrm{TE}$ 's origins are described as follows on its web site:

As part of the University of South Florida's commitment to excellence in teaching, in September 1989, the University proposed the creation of a Center for Teaching Enhancement (CTE) under the State University System's Competitive Grant Program for Enhanced Undergraduate Education. USF's Center for Teaching Enhancement opened on September 4, 1990, with permanent funding (\$143,207 annually) awarded from the State University System's Competitive Grant Program for Enhancing Undergraduate Education. In March 1991, the CTE was awarded a second SUS Competitive Grant for Enhancing Undergraduate Education (\$62,440 annually). These funds created a ten-day summer workshop to help faculty increase student involvement through the use of active learning strategies. (Accessed at: http://www.cte.usf.edu/ on $12 / 12 / 2005$ )

Over time, the center was renamed and its mission grew. As of the time of the case, the $\mathrm{C}^{21} \mathrm{TE}$ described its goals as follows:

(1) facilitate the instructional and career development of faculty and graduate teaching assistants, including the integration of technology, to enhance the quality of teaching and learning in both face-to-face and distributed learning, (2) serve as a resource for groups interested in an inclusive, high quality teaching/learning process and the integration of technology in teaching, and (3) enhance USF's reputation for excellence in both teaching and learning.

To achieve these goals, the $\mathrm{C}^{21} \mathrm{TE}$ was divided into three functional areas. The first, "General Services for Instructors" engaged in a variety of activities, including workshops, course and curriculum planning, individual (confidential) consultations with faculty members, and classroom visits. It also maintained a library of curriculum-related reading materials.

The second $\mathrm{C}^{21} \mathrm{TE}$ function was the Media Innovation Team (MIT). Its staff included instructional designers, multimedia specialists, web course developers, and audiovisual and video production experts. Working together with faculty and community-based clients, the MIT acted to design and implement the integration of technology in teaching and learning.

The final $\mathrm{C}^{21} \mathrm{TE}$ area was Special Programs. This served as a catch-all for many different activities designed to serve faculty and doctoral students. These included: 
- Annual Workshops for New Faculty, Teaching Assistants, and International Teaching Assistants. A week of presentations and seminars, conducted each August (prior to the beginning of classes).

- Innovative Teaching Grant Program. Annual funding for innovative teaching projects up to $\$ 4,000$ for individual faculty and $\$ 10,000$ for department level projects.

- Provost's Award for Outstanding Teaching by a Graduate Teaching Assistant. Annual cash awards and plaques for outstanding Teaching Assistants nominated by their faculty supervisors.

- Increments and Transformations Institute. Using Technology to Enhance Teaching and Learning. Annual program for USF faculty starting with an intensive summer session and continuing with fall and spring components.

In addition to these activities, the $\mathrm{C}^{21} \mathrm{TE}$ was instrumental in organizing a day-long annual symposium, the "USF Symposium on $21^{\text {st }}$ Century Teaching Technologies" that was attended by hundreds of faculty, students and staff. The symposium featured dozens of poster sessions, illustrating effective uses of technology in teaching, presented by both faculty and graduate students. Technology vendors and publishers also set up booths where they could display their products.

The $\mathrm{C}^{21} \mathrm{TE}$ leadership consisted of a Director (Dr. Diane Williams), an Associate Director (William Patterson) and two Assistant Directors. In addition, the center's staff included instructional developers, media designers, audio-visual specialists and administrative support personnel.

\section{Increments and Transformations Institute}

Ever since its inception in 1989, the $\mathrm{C}^{21} \mathrm{TE}$ had been conducting workshops for new and existing faculty members - both year round and in the summer. The content of the two week long intensive summer workshops had primarily been focused on issues of approaches to teaching and learning. All of the topics were related to active learning. For example, one session focused on encouraging student critical thinking. Another one focused on incorporating cooperative learning in the classroom. Connecting with different learning styles was the subject of yet another session.

Within these early workshops, discussions of the impact of technology had played a relatively minor role, with isolated short sessions on incorporating technology into classes and sessions on specific technologies, such as PowerPoint, WebCT and Blackboard. By the beginning of the new millennium, however, it became apparent that technology was starting to impact almost every aspect of teachingboth in the classroom and in distance learning situations. Thus, the Center recognized it was going to have to rethink its approach.

In 2003, the $\mathrm{C}^{21} \mathrm{TE}$ decided to implement a radical new design for its existing summer intensive faculty teaching workshops, renaming it the Increments and Transformations Institute. One of the principal designers of the new ITI was William Patterson, the Associate Director of $\mathrm{C}^{21} \mathrm{TE}$ as well as being a nationally renowned concert violinist. Prior to joining USF in 1997, Bill had worked in faculty development at the University of Central Florida for 5 years and had been responsible for the design and facilitation of over 50 different faculty workshops.

In explaining the approach developed by the $\mathrm{C}^{21} \mathrm{TE}$ after he joined USF, Patterson described the ITI philosophy as follows:

The whole concept was deceptively simple-yet largely unrecognized-in the field of faculty workshop design. We had always hoped that busy faculty would complete workshops focused on enhancing their pedagogical practice (both with and without technology), and then after the workshops would make the time to explore and integrate the most relevant strategies, technologies and concepts into their courses. There has never been any doubt, nor will there be in the future, that this was, in fact, the overarching intent of both the workshop facilitators and the 
faculty participants. But why should we, as faculty developers, have expected an immediate implementation result, especially knowing the vast inherent post-workshop demands faculty would continue to face in the form of their ongoing teaching, research, publication, and service responsibilities? Also, since even small changes in one's teaching involve at least a modicum of risk and considerable time and energy, in the absence of extrinsic motivation, a clear implementation plan, and a sense of collegial community and ongoing support, why would anyone take the risk of making such changes?

To provide both extrinsic motivation and a better defined implementation plan, the ITI was divided into three required phases taking place over the course of an academic year. Using a cohort organization to encourage a sense of group collegiality and support, in place of the sometimes onerous individualized, goit-alone profile that might more typically follow a traditional workshop, the three phases were defined as follows:

- Phase I: A week-long intensive summer workshop (usually preceded by one or more online meetings lasting about an hour) where faculty participants were introduced to both pedagogical concepts (e.g., Bloom's Taxonomy, Perry's Stages, critical thinking, inquiry-based learning) and to a variety of technologies.

- Phase II: Taking place over the subsequent fall semester, each faculty participant was required to implement at least one technology-enabled change (referred to as an "increment") in one or more of their classes. Over the course of the semester, participants got together for two 3-hour sessions where their experiences were presented: once in the middle of the semester and once near the end.

- Phase III: Participants were required to reflect on their experiences, then present these in a formal setting (such as a department meeting) to colleagues, as well as reporting back to the $\mathrm{C}^{21} \mathrm{TE}$ regarding their activities and outcomes.

Participants were paid $\$ 750$ upon completion of each phase, from an annual budget allocation for the ITI that was typically in the range of $\$ 50,000$ to $\$ 70,000$. In addition, a particularly unique aspect of the ITI's design was an optional Phase IV, whereby participants from earlier cohorts were given the opportunity to return to the summer workshop and act as facilitators, receiving a modest stipend. Returning faculty members taking a particularly active role in this phase were sometimes designated as ITI Fellows. In addition to Phase IV involvement, cohort members were also encouraged to facilitate additional workshops throughout the year.

\section{Evolution of ITI Design}

At the time of the case, the ITI had just entered Phase III of Cohort III. Over its two and a half years of operation, the ITI had evolved in a number of ways - some anticipated and some entirely serendipitous.

\section{Cohort I: 2003-2004}

Launching the first ITI proved to be a major undertaking. In order to ensure the success of the approach, Williams and Patterson sought to recruit outside talent to present the first institute's technological and pedagogical content at the Phase I workshop. Towards this end, a consulting firm with a strong reputation in higher education research was retained. One of the founders of the firm delivered the keynote address before a packed house to that year's USF Symposium, and both founders agreed to act as facilitators for the 2003 summer workshop for the first cohort.

Potential participants for the first cohort were selected through nomination by department chairs. These were then screened for appropriateness by the $\mathrm{C}^{21} \mathrm{TE}$. Of particular interest to the Center was recruiting a representative group of faculty from across disciplines, colleges, and career levels and to give priority to 
faculty who had shown an interest in sharing their knowledge with colleagues. Ensuring such a balanced group was the primary criteria used for prioritizing the applicant pool, which was 25-30\% larger than the number of available seats in the cohort.

The workshop schedule, presented as Exhibit 1, consisted of a roughly equal blend of technology related activities, presentations of theory and class discussions. All sessions were moderated by the two founders of the consulting firm, and one additional facilitator from another major university, who were collectively (in concert with Williams and Patterson) responsible for organizing the program. Much of the material was presented at a strategic level, focusing on broad concepts rather than on specific details.

Faculty participant reaction to the workshop was quite positive. In general, comments made in postworkshop evaluations suggested that they were satisfied with the choice of technologies presented and with the balance of technology and conceptual presentations, and that they were also pleased with the presenters.

As Cohort I proceeded through Phase II, it also became clear that the ITI design was achieving its goal of motivating the participant increments to their classes. As summarized in Table 1, the Cohort went well beyond the minimum of one increment per participant. Participants also employed a total of 9 different technologies, including use of new Blackboard (USF's portal/course management system) features, use of MS-Word's "track changes" feature for grading, use of advanced MS-PowerPoint features, use of MSExcel for grading and exercises, developing exercises with a crossword puzzle compiler, use of MS Instant Messenger to communicate with students and use of the Flashlight Online survey tool to assess student progress.

Table 1: Cohort I Results

\begin{tabular}{|l|r|}
\hline Dates & $\mathbf{2 0 0 3 - 2 0 0 4}$ \\
\hline Participant Count & 20 \\
\hline Number of Colleges & 8 \\
\hline Number of Departments & 16 \\
\hline Increment Count & 31 \\
\hline Average Increments Per Participant & 9 \\
\hline Technologies Employed & 1.55 (std dev 1.2) \\
\hline Average Number of Technologies Used Per Participant & 1.35 (std. dev 1.2) \\
\hline
\end{tabular}

One of the most important outcomes of the first cohort came in the form of faculty willing (and eager) to progress to Phase IV. Four of the 20 participants expressed a desire to act as volunteer facilitators and mentors for the next cohort. This interest proved to be enduring; all four had continuing involvement with the ITI through the time of the case.

\section{Cohort II: 2004-2005}

After the successful outcome of Cohort I, the $\mathrm{C}^{21} \mathrm{TE}$ saw little evidence of the need to make major changes in the ITI, excepting that a special priority was placed on recruiting faculty members who were involved in teaching large undergraduate general education courses, a goal established by the university's administration. For that reason, Cohort II started to proceed along very much the same path taken by Cohort I. The second partner in the consulting firm presented at the USF 2004 Symposium. The consultants retained a significant role in designing the summer workshop, although there was the added stipulation (agreed upon by all) that some Cohort I participants would also be given a part to play. Patterson explained:

The typical problem a faculty development center experiences in a university setting is that as few as 2 individuals are responsible for the faculty development of as many as 2500 faculty members. Furthermore, this ratio remains relatively constant over time. What we wanted to do 
was to set in motion a process whereby each year we added to the pool. Instead of 2, we wanted 22 , then 42 , then 62 , and so forth. The only way we could accomplish that was to involve willing volunteers in each cohort to the maximum extent possible.

The design of the Cohort II summer workshop differed from the preceding summer's in a number of ways. First, a substantial fraction of the workshop-the majority of the first two days-was focused on teaching theory, rather than on technology-teaching interactions. In addition, more of the technology content was focused on pedagogy-related tools, such as concept mapping. Second, the consultants were on site for only about two days. For the remainder of the time, they attempted to keep touch with the participants using the synchronous online tool, Elluminate, from their offices and homes in a different part of the country. Third, a substantial amount of workshop time was allocated to interaction with returning members of the previous cohort, both in a social setting one afternoon and through formal presentations on the last day of the workshop. The Cohort II schedule is presented in Exhibit 2.

In their reaction to the workshop, Cohort II participants raised a number of concerns that had not surfaced in the earlier summer. Some of these related to minor issues-such as technical problems during demonstrations and a distracting echo in the headsets that occurred whenever students used Elluminate (a tool designed for communications between separate spaces) in the lab. These prevented sessions from proceeding as smoothly as they could have. Perhaps the greatest issue, however, related to the role of the consultants. Patterson explained the situation as follows:

In Cohort I, we had a group that was satisfied with sessions conducted using projected web pages; Cohort II demanded something more polished, and felt that the web material should have been covered outside of the workshop sessions. For Cohort I, demonstrations of technology were sufficient; Cohort II wanted examples of how these technologies could be used effectively to help them in their classes. For Cohort I, we needed external support to make the process work; Cohort II could already have been self-sustaining — we had moved beyond the consultant stage.

To further underscore this point, participant assessments reported that the most popular component of the workshop - by far-was the session of presentations by previous cohort members that demonstrated the increments that they had implemented. The $\mathrm{C}^{21} \mathrm{TE}$ had always planned to move to a purely self-sustaining model that used prior cohort participants. By the end of Cohort II's Phase I, it became clear that the time had come to make that plan a reality.

The outcomes of Cohort II are presented in Table 2.

Table 2: Cohort II Results

\begin{tabular}{|l|r|}
\hline Dates & $\mathbf{2 0 0 4 - 2 0 0 5}$ \\
\hline Participant Count & 21 \\
\hline Number of Colleges & 4 \\
\hline Number of Departments & 13 \\
\hline Increment Count & 31 \\
\hline Average Increments Per Participant & 13 \\
\hline Technologies Employed & 1.48 (std dev 1.1) \\
\hline Average Number of Technologies Used Per Participant & 1.43 (std. dev 1.1) \\
\hline
\end{tabular}

Coincidentally, shortly after the end of the summer workshop, one of the Cohort II participants—-Dr. Grandon Gill, a faculty member in the Information Systems and Decision Sciences department within USF's College of Business - approached Williams and Patterson with a proposal. He explained that his education (MBA and DBA from Harvard Business School), his teaching and his research had all revolved around the use of case studies. What he proposed to do was to develop a series of cases on Cohort I and II teaching situations and to make the discussion of these cases the basis for the Cohort III workshop. As evidence of how serious he was about the project, Gill also presented them with two completed sets of 
cases_-both detailing challenging situations he had faced in his own technology-enabled teaching activities.

Gill's credibility in proposing the change was strengthened by the fact that he had been a Cohort II participant and had therefore been privy to the private discussions between participants throughout the week. He argued that in-depth discussion of case studies was an appropriate pedagogy to use with faculty members primarily based on parallels he was able to draw with business education, particularly executive education. The parallels included the following observations:

- Like business, teaching is a field where many different strategies can be successful if implemented properly. Thus, any attempt to proclaim a "right way" to teach is doomed to failure. The best one can hope for is to expose participants to a variety of approaches.

- Teaching situations, like business situations, do not lend themselves to simple, paragraph-long, descriptions. Many factors come into play - the nature of the content, the nature of the students, the goals of the institution, the facilities that are available and the nature of the instructor, both with respect to skills and career aspirations. Only through understanding the interaction of these factors can we come to a successful teaching solution. The easiest way to develop such an understanding is through discussion with other faculty members.

- Like executives, even junior faculty members have a wealth of experience relating to their practice - that being effective teaching. Even if they have not yet spent much time delivering it, they have certainly been on the receiving end of many examples. Thus, every participant should have valuable insights to share.

- Also like executives, nearly all faculty members come into the profession with a desire to be center-stage. Since they almost universally like to hear themselves talk, they are perfect candidates for discussion-based learning.

Faced with justifications such as these, Williams and Patterson agreed to try some case discussions during the Cohort III summer workshop. They also offered to help Gill identify some possible case sites.

\section{Cohort III: 2005-2006}

The development of the Cohort III case materials proceeded in parallel with the Cohort II Phase II and Phase III activities. During the fall semester, another case-involving the challenges of getting graduate students in gifted education to work together (Gill and Shaunessy, 2006)—was developed. In spring, two additional cases_-one involving Classroom Performance Systems (Gill, El Rady and Myerson, 2006) and one involving a Cohort III member contemplating what changes he might like to make to his classes (Gill and Reeves, 2006) — were developed. At that point, sufficient cases had been developed to allow for one each day of the workshop-excluding the first (reserved for introducing the ITI and participants) — with another sequential series of cases available for online discussion (EMBA 2002 (A), (B) and (C); Gill, 2006).

The set of cases used for the preliminary online discussions_EMBA 2002 (A), (B) and (C) —had been developed previously by Gill to be used as a lead off case for all of his business discussion classes. It described Gill's experiences dealing with a difficult group of Executive MBA students who were not sure that they wanted to participate in a case method course and the challenges he faced when they had started to email the program director with their complaints after the first class meeting. Within the case, the philosophy behind the case method and details on how a classroom case discussion was conducted were woven into the fabric of the situation. It had worked well with his masters students in the past, and he hoped it would also prove suitable for faculty use. 
In selecting the other case sites, Gill had tried to get as broad a range of disciplines and technologies as possible. In parallel with his efforts, Williams and Patterson established a goal that every technology mentioned in any of the cases should be employed - for teaching purposes, not just for demonstrationwithin the workshops. Towards this end, a $\mathrm{C}^{21} \mathrm{TE}$ representative approached TechSmith and managed to acquire a donation of twenty-five licenses for Camtasia Studio (central to one of the cases and relevant to another) and used the product to create software demonstrations. The Center also arranged for an eInstruction Classroom Performance System to be donated, so participants would be able experience what is was like to use an audience response system (in the role of student) as well as seeing how it was set up.

In mid-spring 2005, a structure for the summer workshop was proposed based upon each day beginning with a case discussion and ending with a small group activity involving reading and developing study questions for the next day's case. Sandwiched between the case-related activities would be presentations from previous cohorts, demonstrations and hands-on lab activities. To make room for these activities, Gill proposed eliminating nearly all theory based content. The only exception to this was made where theory was presented in the context of a technology tool used to illustrate it. Thus, critical thinking was explored via a web-based interactive site (developed by a participant from Cohort I) that was designed to teach counselors about critical thinking. On a similar vein, inquiry-based research was to be demonstrated in the context of an exploration of library and web-search activities presented by a library sciences faculty member (also from Cohort I). In addition to specific content, Gill proposed that one morning's session be conducted entirely online from the homes or offices of participants. Doing so, he argued, would accomplish two objectives. First, it would eliminate the technical issue of echoes that had troubled Cohort II. Second, it would serve to drive home a very tangible benefit of going online: the ability to choose your own location. The proposed structure was approved and, with some modification, became the official Cohort III schedule, shown in Exhibit 3.

The initial response to the new workshop design was mixed. While some participants in the online presessions were very enthusiastic about the process, and made numerous contributions to the asynchronous discussions, others expressed reservations. Specifically, they were concerned that the case method would be ineffective in teaching them what they wanted to learn. As the workshop week progressed, however, attitudes began to change. Much as Gill had observed with executives, participants seemed to enjoy the opportunity to share their experiences-an opportunity that naturally (and frequently) arose during the course of the discussions. In addition to Gill, several participants from previous cohorts were brought in to facilitate all or part of the last three discussions. Not only did this change serve to break the monotony of a single facilitator, it also set the stage for broader participation in future cohort workshops.

Another aspect of the Cohort III design that differed from previous cohorts was the decision to supply participants with a PDA (Wireless-enabled Palm Tungsten and accessories). Many of the participants had no access to personal laptops and Patterson and Williams had felt that - in addition to the productivity benefits such a device could offer-it could prove an effective tool for presenting lecture slides. The funding for the PDA's had been a consequence of savings from not using any outside facilitators in the workshop and the hardware's unexpected appearance on the first day of the workshop had left participants almost speechless with delight.

At the time of the case, the Cohort III progress reports (for their Phase II activities) had just been received. The results, presented in Table 3, proved to be extremely gratifying for the ITI staff and facilitators. Both the number of increments and number of technologies employed were nearly double those from previous cohorts-which had already been characterized as highly successful. In addition, a substantial fraction of the reports included unsolicited expressions of gratitude to the $\mathrm{C}^{21} \mathrm{TE}$ for offering the workshop. 
Table 3: Cohort III Results

\begin{tabular}{|l|r|}
\hline Dates & 2005-2006 \\
\hline Participant Count & 20 \\
\hline Number of Colleges & 5 \\
\hline Number of Departments & 16 \\
\hline Increment Count & 61 \\
\hline Average Increments Per Participant & 19 \\
\hline Technologies Employed & 3.05 (std. dev 1.6) \\
\hline Average Number of Technologies Used Per Participant & 2.60 (std. dev. 1.4) \\
\hline
\end{tabular}

\section{Discussion}

A cursory statistical analysis of the difference between the Cohort I \& II combined mean and the mean of Cohort III shows that the change in participant activity level, for both increments and number of technologies used, was significant at the $\mathrm{p}<0.01$ level (see Table 4). Since inspection alone tells us that the Cohort I and II results were nearly identical, we can conclude that something very different was happening in Cohort III. What is less clear is the degree to which we can attribute the increase in participant activity to the use of the case method.

Table 4: t-test for Equality of Means between Cohorts I\&II (combined) and III

\begin{tabular}{|l|l|l|l|l|l|l|l|}
\hline & $\mathbf{t}$ & df & $\begin{array}{l}\text { Sig. (2- } \\
\text { tailed) }\end{array}$ & $\begin{array}{l}\text { Mean } \\
\text { Difference }\end{array}$ & $\begin{array}{l}\text { Std. Error } \\
\text { Difference }\end{array}$ & \multicolumn{2}{|l|}{$\begin{array}{l}\text { 95\% Confidence Interval } \\
\text { of the Difference }\end{array}$} \\
\hline & & & & & & Lower & Upper \\
\hline Increments & 3.717 & 27.986 & .001 & 1.538 & .414 & .690 & 2.385 \\
\hline Technologies & 3.392 & 31.310 & .002 & 1.210 & .357 & .483 & 1.937 \\
\hline
\end{tabular}

In interpreting these findings, two common sources of error can reasonably be rejected. The Hawthorne effect-whereby observing activities leads to their improvement-does not appear to be applicable. Cohort I - as the initial group - was observed at least as closely as Cohort III and all three cohorts followed essentially the same procedure in Phases II and III. Similarly, the effect does not appear to be an example of the learning curve. Were that the case, greater differences between Cohorts I and II should have been observed. Furthermore, the substantial changes made between Cohorts II and III are more suggestive of a process change, as opposed to the types of refinements to existing processes that are normally typical of learning curve situations.

What is less clear is what percentage of the improvement between Cohorts II and III can be attributed to the use of the case method, and what can be attributed to other factors-particularly the skills of the instructors, the make up of the cohort and the participation of previous cohort members. With respect to the first of these, although Gill's experience in case writing and discussion leadership certainly contributed to the Cohort III workshop, it can be argued that the strong relationship that was established between Cohort I and the consultants should have contributed in similar fashion to those results. Certainly, their national prominence far exceeded any local reputation Gill might have developed within the USF community. Similarly, while each cohort certainly had its own unique characteristics, the cohort selection process instituted by $\mathrm{C}^{21} \mathrm{TE}$ was specifically designed to produce a diverse yet balanced group. We could find no obvious reason to believe that one group should have been expected to outperform the 
others, although we certainly can't discount the likelihood that cohort differences accounted for some of the variations in performance.

The participation of previous cohort members in the Cohort III workshop is much harder to discount as a factor. Indeed, we believe they may have played an important role. While it is true that there were also previous cohort contributions to Cohort II, the nature of those contributions was very different in character and timing. As previously noted, in Cohort II the previous cohort presentations occurred the morning of the last day of the workshop. In many ways, their impact was a mixed blessing, according to several cohort participants. On the one hand, the presentations were an inspiration to the Cohort II participants - who saw the types of increments that could be implemented. On the other, they served as an irritant - focusing the group on all the technologies that they felt they should have learned, but didn't. In Cohort III, prior cohort presentations were scheduled on the first day of the workshop (by design) and returning participants played a far greater role in every aspect of the workshop, from tutorials to presentations to case facilitation. We believe that mentor role definitely contributed to the Cohort III outcome, although the magnitude of that contribution cannot be gauged precisely.

With respect to the role played by the use of the case method, participant feedback-particularly from those faculty members who expressed initial skeptical regarding the approach-leads us to believe that it had a major impact on cohort outcomes. Perhaps even more importantly, the discussions themselves were highly animated and suggested that virtually everyone involved was engaged. As an additional piece of evidence, whereas finding potential case sites in Cohort I and II was challenging, as of the time this case was written, Gill had already received more Cohort III volunteers to act as new case sites than could be utilized in Cohort IV (since only 4-5 cases could be discussed per workshop).

One final issue related to the ITI program is that of generalizability. To what extent could the results be replicated at other institutions, perhaps using case studies not developed locally (such as those developed by the $\mathrm{C}^{21} \mathrm{TE}$, being made available through publication in Informing Faculty)? Based on the ITI experience, having locally developed case studies is not a prerequisite for a successful outcome using the three phase model presented here-Cohorts I \& II demonstrated this. Assuming a reasonably skilled facilitator is available (and even non-case method business schools usually have some of these, as do many colleges of education), we therefore believe that use of non-local cases can lead to highly effective workshops - assuming the same basic model used for the ITI is employed. We also believe, however, that having locally developed case studies and returning cohort participants can energize a workshop; we observed this to be particularly true when case protagonists were in the room and available for questions after the discussion has been completed. We would therefore encourage institutions interested in implementing their own ITI model to attempt to develop some of their own cases and use as many of their own facilitators as possible. Once developed, these cases can (and should) then be made available to other institutions through journals such as Informing Faculty. In the long run, we believe this process could lead to measurable improvements in the effective use of technology for teaching throughout higher education.

\section{Conclusions}

A particularly interesting contribution to the debate of theory versus practice in education was made by Kessels and Korthagen (1996), who propose that in order to understand the nature of the problem we need to go back to the historical literature-all the way back to the Greek philosophers, such as Aristotle. They contrasted the notion of scientific understanding (episteme) with that of practical wisdom (phronesis), noting that the latter:

....is essentially a different kind of knowledge, not concerned with scientific theories, but with the understanding of specific concrete cases and complex or ambiguous situations (Kessels and Korthagen, 1996, p. 19) 
The authors further note that whereas episteme tends to be driven by general principles, phronesis tends to be driven by specific facts. In other words, the contingencies of complex situations tend to override whatever general theories are familiar to us.

The approach utilized in the ITI has led to outcomes that clearly demonstrate the power of phronesis as a tool. For phronesis is enabled, first and foremost, by "concrete situations to be perceived, experiences to be had, persons to be met, plans to be exerted, and their consequences to be reflected on." (Kessels and Korthagen, 1996, p. 21) Although no learning environment - except real world experience-can provide all of these elements, the ITI approach of using case studies and bringing cohorts together (Phase I), requiring participants to plan their increments and implement them (Phase II), and having participants reflect upon their outcomes and communicate their findings to others (Phase III) would seem to be as close a fit as can be achieved in any academic endeavor.

\section{References}

Brunetti, G.J. (1998) Teacher Education: A Look at Its Future, Teacher Education Quarterly, 25(4), 59-64

Chi , M.T.H and Glaser, R. (1985) Problem Solving Ability, In Sternberg, R.J. (1985) Human Abilities: An Information Processing Approach, New York: Freeman, 227-250

de Kleer, J. and Brown, J.S. (1981) Mental Models of Physical Mechanisms and Their Acquisition. In Anderson, J.R. Cognitive Skills and Their Acquisition. Hillsdale, NJ: Erlbaum, 285-309

Gill, T.G. (2005) The Peer Reviews and the Programming Course, Issues in Informing Science and Information Technology, 2, 205-217.

Gill, T.G. (2006). EMBA 2002 (A), (B) \& (C). Informing Faculty, 1(1). 1-22

Gill, T.G. (2006). The Mystery of the Self-Paced Course (A) \& (B). Informing Faculty, 1(3). 1-26

Gill, T.G., El Rady, J. and Myerson, M. (2006). Classroom Performance Units in Human Sexual Behavior. Informing Faculty, 1(4). 1-26

Gill, T.G. and Reeves, K. (2006) Getting Started with Increments and Transformations. Informing Faculty, 1(5). 115

Gill, T.G. and Shaunessy, E. (2006). Gifted Education Counseling: A Web-Based Course. Informing Faculty, 1(2). $1-18$

Hayes, R. H., \& Abernathy, W. J. (1980) Managing our way to economic decline, Harvard Business Review, JulyAugust. 67-77.

Jones, A.H. (1998) Ten Points of Debate in Teacher Education: Looking for Answers to Guide Our Future, Teacher Education Quarterly, 25(4), 9-15

Kessels, J and Korthagen, F. (1996). The Relationship of Theory to Practice: Back to the Classics, Educational Researcher, 25(3), 17-22.

Pascoe, G.W. (1992) Execution makes it happen: Have marketing educators forgotten? Management Education and Development, 23, 140-154

Peters, T.J. and Waterman, R.H. (1982), In Search of Excellence, New York: Warner. 


\section{Exhibit 1: Cohort I Schedule}

\begin{tabular}{|c|c|}
\hline $\begin{array}{l}\text { 1. Day \& time } \\
\text { of session }\end{array}$ & 2. Session Title and Description \\
\hline $\begin{array}{l}\text { Probably } \\
\text { Wednesday, } \\
\text { July } 16, \\
4 \mathrm{pm}\end{array}$ & $\begin{array}{l}\text { Preparatory synchronous event and survey to help finalize the agenda for the week. One } \\
\text { priority, for example: identify issues for teaching case studies and to help participants } \\
\text { become familiar with the online technology. Goal: become familiar with conferencing } \\
\text { strategies, show example of teaching case study, brainstorm topics. }\end{array}$ \\
\hline $\begin{array}{l}\text { Monday, July } \\
21\end{array}$ & $\begin{array}{l}\text { Overall focus for Monday is to introduce the Institute, and work on incremental } \\
\text { approaches to improving TLT. }\end{array}$ \\
\hline 9 am-12 & $\begin{array}{l}\text { Goals and motives for using technology to improve learning. Broadly important goals } \\
\text { (e.g., seven principles of good practice, information literacy) and personalized } \\
\text { approaches. } \\
\text { Incremental strategies } \\
\text { "Why Bother?" "Low Threshold Activities" "Seven principles" "Personalizing } \\
\text { Pedagogy" "Information Literacy" "Building Community Online and On Campus" - } \\
\text { participants will explore this catalog of relevant ideas, develop a description of one or } \\
\text { more such ideas to add to the database, and discuss how might a resource like this help } \\
\text { others at USF. } \\
\text { Initial feedback from participants } \\
\text { Building community online }\end{array}$ \\
\hline $12-1: 30$ & Lunch \\
\hline $1: 30-2: 30$ & $\begin{array}{l}\text { Building community online (cont’d) } \\
\text { Feedback from participants and discussion of progress so far }\end{array}$ \\
\hline $2: 30-3: 00$ & $\begin{array}{l}\text { Face-to-face is not always an ideal setting for interaction. Sometimes the ability to bridge } \\
\text { distance can be an advantage, for example if it becomes possible to include a more varied } \\
\text { group of people in the conversation. Session will explore several ways in which these } \\
\text { differences and distances can become a strength. Participants will brainstorm } \\
\text { applications of these ideas to their own courses. }\end{array}$ \\
\hline $3: 00-3: 15$ & Introduction to Deconstructing Instructional Resources \\
\hline $3: 15-4: 00$ & $\begin{array}{l}\text { The dark side of learning with technology - what problems might such improvements } \\
\text { cause? Introduce the teaching case study ideas that will be the focus for Tuesday } \\
\text { morning and brainstorm additional topics to explore on Tuesday morning }\end{array}$ \\
\hline 4:00-4:30 & Review and planning or exploratory session; \\
\hline $\begin{array}{l}\text { Tuesday, July } \\
22\end{array}$ & $\begin{array}{l}\text { Teaching case studies - each case study illustrates a problem that faculty sometimes } \\
\text { encounter in teaching with technology, a problem that is worth significant analysis and } \\
\text { creative thinking together. The morning will begin with discussion of one or two } \\
\text { previously prepared cases, and then participants will describe their own issues. Each } \\
\text { case will be analyzed in small groups, answering two basic questions: } \\
\text { a) What are the issues or causes under the surface of the events described in the } \\
\text { case? } \\
\text { b) How might a faculty member respond to these issues? }\end{array}$ \\
\hline $11: 30-1: 00$ & Lunch \\
\hline
\end{tabular}




\begin{tabular}{|c|c|}
\hline 1:00-4:00 pm & $\begin{array}{l}\text { Classroom research for incremental improvement - study ideas for classroom research; } \\
\text { develop personal plans; introducing Flashlight Online and relevant packages such as the } \\
\text { PowerPoint self-study kit. Faculty participants should have Flashlight Online accounts. } \\
\text { Part of this session should occur in a networked computer lab so that participants can } \\
\text { create their own surveys online. Primary goal for each participant: draft a survey that } \\
\text { could help him or her a) implement an LTA or b) respond to an issue described in one of } \\
\text { the case studies. }\end{array}$ \\
\hline 4:00-4:30 & Review and planning \\
\hline $\begin{array}{l}\text { Wednesday } \\
\text { 9:00-12:00 }\end{array}$ & $\begin{array}{l}\text { Seven Step Workshop (part I). This part of the Institute guides participants through a } \\
\text { process of redesigning a course (or, if participants choose, a sequence of 2-3 courses.) } \\
\text { During the morning, participants will work on Step } 1 \text { (“What do I want my students to } \\
\text { have learned?”), Step } 2 \text { (“Identify best teaching-learning approaches”), Step } 3 \text { (“Plan } \\
\text { major assignments and exams”), Step } 4 \text { (“Plan spaces, times and sequences for } \\
\text { learning”) }\end{array}$ \\
\hline 12:00 - 1:30 & Lunch \\
\hline $1: 00-1: 45$ & Begin Step 5 (“What Technological Tools Can Do, and Not Do”) \\
\hline 1:45-3:00 & $\begin{array}{l}\text { Participate in Webcast on uses of Chat in instruction. Introduce synchronous tools } \\
\text { available to USF faculty }\end{array}$ \\
\hline 3:00-4:00 & Continue step 5 \\
\hline 4:00-4:30 & Review and planning \\
\hline $\begin{array}{l}\text { Thursday } \\
\text { 9:00 - 12:00 }\end{array}$ & $\begin{array}{l}\text { Seven Step Workshop: Complete Step 5. Step } 6 \text { (“Sequences to Learning: Choose } \\
\text { Technologies”). Step } 7 \text { (“Implementation Issues”) }\end{array}$ \\
\hline 12:00-1:30 & Lunch \\
\hline 1:30 - 3:00 & $\begin{array}{l}\text { Strategic visions. Moving further up the scale toward transformation, this afternoon we } \\
\text { will discuss ways in which technology use might already be affecting the University's } \\
\text { mission, identity, and development. Parallels between today and previous } \\
\text { transformations (reading/writing/printing; development of universities) will be explored } \\
\text { in order to gain insight into opportunities and dangers facing USF today. }\end{array}$ \\
\hline 3:00-4:00 & $\begin{array}{l}\text { Participants will explore other visions of improvement and transformation. "Education, } \\
\text { technology, and the human spirit" }\end{array}$ \\
\hline 4:00-4:30 & Review and planning. \\
\hline $\begin{array}{l}\text { Friday } \\
9-12\end{array}$ & $\begin{array}{l}\text { Evaluating strategic change - in this second session on evaluation and assessment, } \\
\text { participants will draft a study plan for a) guiding the improvement they planned during } \\
\text { the } 7 \text { step workshop, or b) guiding some other large-scale improvement effort in which } \\
\text { they are involved. All or part of this session will take place in a computer laboratory so } \\
\text { that participants can use Flashlight Online. }\end{array}$ \\
\hline $12-1: 30$ & Lunch \\
\hline $1: 30-3: 30$ & $\begin{array}{l}\text { Outreach planning and Next Steps for the program and for individuals, including } \\
\text { discussion of the situation facing compassionate pioneers. Topics for follow-on [Online] } \\
\text { brownbag sessions and strategies for a) building attendance, and b) helping the brown } \\
\text { bags achieve larger objectives. }\end{array}$ \\
\hline
\end{tabular}


Exhibit 2: Cohort II Schedule

\begin{tabular}{|c|c|c|c|c|}
\hline Monday, July 19 & Tuesday, July 20 & Wed, July 21 & Thursday, July 22 & Friday, July 23 \\
\hline $\begin{array}{l}\text { 9:00 Opening Reception, } \\
\text { Grace Allen Room } \\
\text { 9:15 Introductions and } \\
\text { Institute overview } \\
\text { 10:30 BREAK } \\
\text { 11:00 Elluminate session } \\
\text { with Outside Facilitator \#1 } \\
\text { and Outside Facilitator \#2, } \\
\text { LIB } 209 \\
\text { 12:00 Lunch on your own } \\
\text { 1:30 Assessment survey } \\
\text { software introduction, LIB } \\
\text { 209 } \\
\text { 3:00 BREAK } \\
\text { 3:30 Inquiry-based } \\
\text { learning } \\
\text { A conversation with Drew } \\
\text { Smith, Cohort I, (Library } \\
\text { and Information Science), } \\
\text { LIB } 209 \\
\text { 4:30 Adjourn }\end{array}$ & $\begin{array}{l}\text { Critical Thinking Skills } \\
\text { Facilitators: } \\
\text { Invited Faculty Members, } \\
\text { University of Texas El } \\
\text { Paso } \\
\text { 9:00 Session One, Grace } \\
\text { Allen Room } \\
\text { 10:30 BREAK } \\
\text { 10:45 Session Two } \\
\text { 12:15 Lunch } \\
\text { 1:30 Session Three } \\
\text { 3:30 Wrap up }\end{array}$ & $\begin{array}{l}\text { 9:00 Session I with } \\
\text { Outside Facilitator \#1 and } \\
\text { Outside Facilitator \#2, } \\
\text { Grace Allen Room } \\
\text { 10:45 BREAK } \\
\text { 11:00 Session with virtual } \\
\text { guest presenter, LIB } 209 \\
\text { 12:00 Lunch } \\
\text { 1:30 p.m. Session II with } \\
\text { Outside Facilitator \#1, } \\
\text { Outside Facilitator \#2, and } \\
\text { guest facilitator, Deirdre } \\
\text { Cobb-Roberts, Cohort I, } \\
\text { (Psychological and Social } \\
\text { Foundations), Grace Allen } \\
\text { Room } \\
\text { 3:30 p.m. BREAK } \\
\text { 3:45 p.m. Reception with } \\
\text { Cohort I and II. } \\
\text { 4:30 p.m. Adjourn }\end{array}$ & $\begin{array}{l}\text { 9:00 Assessment Design } \\
\text { with Outside Facilitator \#2 } \\
\text { and Outside Facilitator \#1, } \\
\text { Grace Allen Room } \\
\text { 10:30 a.m. BREAK } \\
\text { 10:45 a.m. Applying new } \\
\text { skills, LIB } 209 \\
\text { 12:00 Lunch } \\
\text { 1:30 Session II, More on } \\
\text { technology for teaching, } \\
\text { Outside Facilitator \#1 and } \\
\text { Outside Facilitator \#2 } \\
\text { 3:00 BREAK } \\
\text { 3:15 Question and } \\
\text { Answer session } \\
\text { 4:00 Adjourn }\end{array}$ & $\begin{array}{l}\text { 9:00 A visit with Cohort I } \\
\text { members, examples of } \\
\text { activities and materials, } \\
\text { Grace Allen Room } \\
\text { 11:00 Looking ahead to } \\
\text { Phase Two } \\
\text { 12:00 Lunch } \\
\text { 1:30 p.m. Elluminate (2:00 } \\
\text { p.m.) session with Outside } \\
\text { Facilitator \#1 and Outside } \\
\text { Facilitator \#2, LIB } 209 \\
\text { 3:30 Wrap up }\end{array}$ \\
\hline
\end{tabular}

Note: Names of outside participants have been removed. 


\section{Exhibit 3: Cohort III Schedule}

\section{Pre-workshop activities:}

14 July 2005: Elluminate orientation and EMBA (A) case discussion assignments given

14-20 July 2005: EMBA case discussion occurs asynchronously, on Blackboard

20 July 2005: Elluminate discussion of EMBA (B) \& (C)

Workshop week activities:

\begin{tabular}{|c|c|c|c|c|c|}
\hline Date/Time & Monday, 7/25/05 & Tuesday, 7/26/05 & Wednesday, 7/27/05 & Thursday, 7/28/05 & Friday, 7/29/05 \\
\hline 9:00 - 9:30 AM & Pastries and juice & Pastries and juices & At home online & Pastries and juice & Pastries and juice \\
\hline 9:30-10:30 AM & $\begin{array}{l}\text { Welcome and } \\
\text { introductions, } \\
\text { Handout } \mathrm{C}^{21} \mathrm{TE} / \mathrm{MIT} \\
\text { services. Survey technology } \\
\text { background and Institute } \\
\text { goals. } \\
\text { Diane and Carol }\end{array}$ & $\begin{array}{l}\text { Class discussion: } \\
\text { Counseling Gifted } \\
\text { Students: A Web Based } \\
\text { Course } \\
\text { Grandon Gill with } \\
\text { guest Elizabeth } \\
\text { Shaunessy } \\
\text { CRU survey at end of } \\
\text { case? }\end{array}$ & $\begin{array}{l}\text { Online class discussion: } \\
\text { Mystery of the Self-Paced } \\
\text { Course (A) } \\
\text { Grandon Gill } \\
\text { (Shauna Schullo) }\end{array}$ & $\begin{array}{l}\text { Class discussion: } \\
\text { Classroom Response } \\
\text { Units in Human Sexual } \\
\text { Behavior } \\
\text { Grandon Gill and } \\
\text { Carlos Zalaquett with } \\
\text { guests Johnny ElRady } \\
\text { and Marilyn Myerson }\end{array}$ & $\begin{array}{l}\text { Class discussion: } \\
\text { Getting Started With } \\
\text { Increments and } \\
\text { Transformations } \\
\text { Grandon Gill and } \\
\text { Drew Smith with guest } \\
\text { new cohort III member } \\
\text { Kingsley Reeves }\end{array}$ \\
\hline 10:30-12:00 PM & Cohort I \& II presentations & $\begin{array}{l}\text { Camtasia demo and } \\
\text { orientation } \\
\text { Grandon Gill } \\
\text { (Neil Gomes) }\end{array}$ & $\begin{array}{l}\text { Online Elluminate } \\
\text { Moderator Development } \\
\text { Shauna Schullo, }\end{array}$ & $\begin{array}{l}\text { CPS demo and } \\
\text { orientation } \\
\text { Grandon Gill } \\
\text { (Johnny ElRady) }\end{array}$ & $\begin{array}{l}\text { Getting started, } \\
\text { refection and sharing } \\
\text { discussion }\end{array}$ \\
\hline 12:00-1:00 PM & Lunch & Lunch & Lunch and travel & Lunch & Lunch \\
\hline
\end{tabular}




\begin{tabular}{|c|c|c|c|c|c|}
\hline 1:00-2:30 PM & $\begin{array}{l}\text { PDA with Margi, one hour: } \\
\text { Distribute PDAs } \\
\text { Bill } 10 \text { min intro } \\
\text { Neil PDA presentation } 50 \\
\text { min; Distribute CRUs, } \\
\text { Grandon on clickers, } 30 \\
\text { min }\end{array}$ & $\begin{array}{l}\text { Flashlight } \\
\text { Neil one hour; } \\
\text { Rave Wireless demo } \\
\text { team } 30 \text { min }\end{array}$ & $\begin{array}{l}\text { Tablet PC Grandon and } \\
\text { Neil one hour; } \\
\text { Exilim camera Bill } 5 \\
\text { minute intro and Neil } 25 \\
\text { min session }\end{array}$ & $\begin{array}{l}\text { Critical Thinking } \\
11 \frac{1}{2} \text { hours } \\
\text { Carlos Zalaquett } \\
\text { Bloom's, Monk, } \\
\text { revised handouts } \\
\text { Use Tablet PC and One } \\
\text { Note }\end{array}$ & $\begin{array}{l}\text { Inquiry } \\
\text { 1²/2 hours } \\
\text { Drew Smith } \\
\text { Theory of Inquiry, } \\
\text { Library Internet for } \\
\text { inquiry research, e.g. } \\
\text { Google, Pronto } \\
\text { Use Treo }\end{array}$ \\
\hline 2:30-3:59 PM & $\begin{array}{l}\text { Case preparation \& small } \\
\text { group discussion: } \\
\text { Counseling Gifted Students: } \\
\text { A Web Based Course } \\
\text { Use PDA to create a group } \\
\text { question }\end{array}$ & $\begin{array}{l}\text { Case preparation \& } \\
\text { small group discussion: } \\
\text { Mystery of the Self- } \\
\text { Paced Course (A) }\end{array}$ & $\begin{array}{l}\text { Case preparation \& small } \\
\text { group discussion: } \\
\text { Classroom Response } \\
\text { Units in Human Sexual } \\
\text { Behavior }\end{array}$ & $\begin{array}{l}\text { Case preparation \& } \\
\text { small group discussion: } \\
\text { Getting Started With } \\
\text { Increments and } \\
\text { Transformations }\end{array}$ & $\begin{array}{l}\text { Concluding remarks } \\
\text { and evaluations }\end{array}$ \\
\hline 3:59-4:00 PM & Minute survey & Minute survey & Minute survey & Minute survey & \\
\hline
\end{tabular}

